\title{
A multilevel UPQC for voltage and current quality improvement in distribution system
}

\author{
Veera Nagi Reddy. V' ${ }^{1}$, D. V Ashok Kumar ${ }^{2}$, Venkata Reddy Kota ${ }^{3}$ \\ ${ }^{1}$ Research Scholar, Jawaharlal Nehru Technological University, India \\ ${ }^{2}$ Department of EEE, Rajeev Gandhi Memorial College of Engineering and Technology, India \\ ${ }^{3}$ Department of of EEE, Jawaharlal Nehru Technological University, India
}

\begin{tabular}{l}
\hline \hline Article Info \\
\hline Article history: \\
Received Feb 18, 2019 \\
Revised May 12, 2019 \\
Accepted Jul 8, 2019 \\
\hline Keywords: \\
Cascaded h-bridge \\
Current quality \\
Distribution system \\
Multi-level \\
Power quality \\
UPQC \\
Voltage quality \\
\hline
\end{tabular}

\begin{abstract}
Unified Power Quality Conditioner (UPQC) is substantial power conditioner in power system to filter the power system parameters with an objective to improve the quality of power delivered to the customers/utility point. This paper presents a multi-level UPQC to enhance the quality in power distribution system. The series and shunt controllers of UPQC gives out five leveled output which is further filtered to feed compensating signals to improve voltage and current profiles in power distribution system. Series and shunt controllers of UPQC are structured with cascaded H-Bridge (CHB) topology to deliver compensating signals. Two separate control strategies are employed to regulate the power switches of 5-level CHB series and shunt controllers of UPQC. Sag and swell in source voltage and harmonics in source current are strained with UPQC. The proposed system is developed and results are obtained using MATLAB/SIMULINK software.
\end{abstract}

Copyright (c) 2019 Institute of Advanced Engineering and Science. All rights reserved.

\section{Corresponding Author:}

Veera Nagi Reddy.V, Research Scholar, Jawaharlal Nehru Technological University, Kakinada, A.P, India. Email: vvnr352@gmail.com

\section{INTRODUCTION}

The Power quality definition differs for different sections in power system. To the power provider, power quality defines the standard of power supplied to the customer with respect to his ability with due reliability and regulation of voltage and frequency. To the consumer, the statement of quality in power [1-3] focus on their ability to utilize the supplied power with précised signal magnitude and shape.

Power quality issues $[4,5]$ are not only associated with system efficiency and environmental issues but to uninterrupted supply and quality of power in the system. Some power quality problems are of short duration issues and some are long duration. If the power quality issue persists for less than one minute it is termed as short duration and if the problem persists for more than one minute, the power quality issue is termed to be long duration. Even a short-term power quality problem can degrade the system performance inducing unwanted operation of the power system.

Worsen of voltage or current in power distribution system is due to large usage of non-linear equipments and power electronic converters. Power electronic converters like rectifiers, thyristor converters are non-linear type of loads and produce large disturbance in ac mains. There are two approaching techniques to the mitigation of voltage and current quality problems. The first approaching technique is load conditioning, which fortifies that the operating equipment is made insensitive to power disturbances, which in turn allows the operation even under significant current and voltage distortion. The second apparoaching technique is to install line-conditioning systems that counteract or suppress the electrical power system disturbances. 
Power quality is improved using FACTS [6-10] devices like DVR [11-15], DSTATCOM [16-22], UPQC and many more. UPQC is a combination of back-to-back series-shunt controllers connected with a common DC-Link voltage and combines the performance of DVR and DSTATCOM. UPQC [23-26] enhances the system performance filtering out the disturbances like sag/swell in source voltage and ensures load is supplied with constant voltage. UPQC also reduces the distortions (due to harmonics) in source currents that are produced due to non-linear load connections. Block representation of UPQC in power system is shown in Figure 1.

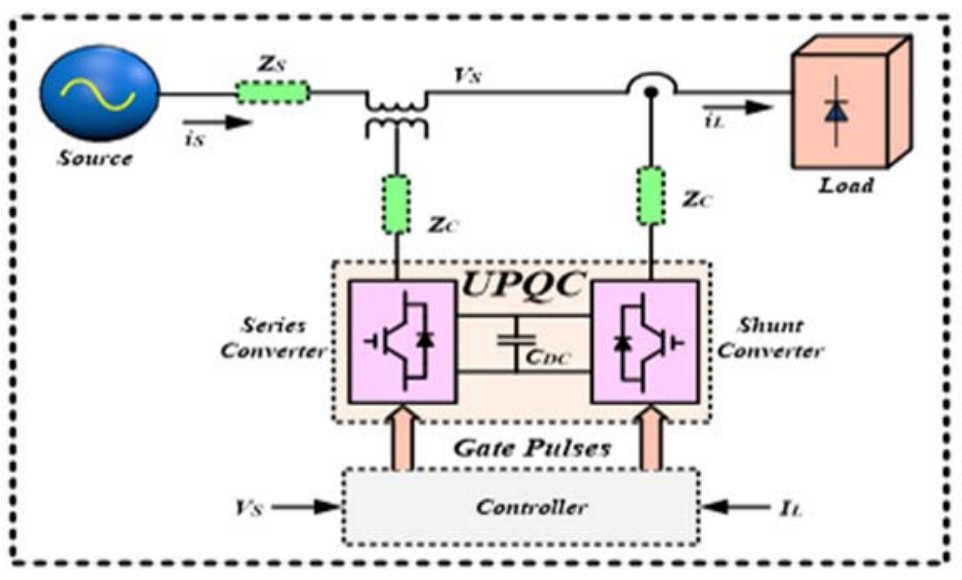

Figure 1. Block representation of UPQC in power system

This paper presents a multi-level UPQC to enhance the quality in power distribution system. The series and shunt controllers of UPQC gives out five leveled output which is further filtered to feed compensating signals to improve voltage and current profiles in power distribution system. Series and shunt controllers of UPQC are structured with cascaded H-Bridge (CHB) topology to deliver compensating signals. $\mathrm{Sag} /$ swell in source voltage and harmonics in source current are strained with UPQC.

\section{CASCADED H-BRIDGE FIVE-LEVEL UPQC}

Conventional square-wave inverter yields square wave output, which contains very large quantity of harmonics. This insists for high sized filters to tune the output to bring sinusoidal form. Cost and size of filter increases, which becomes a major drawback while using conventional square-wave inverters.

Multi-level inverter draws attention due to its meritorious characteristics giving out leveled output. Levelled output requires less sized filters as compared to conventional square-wave inverters. Cascaded HBridge topology of multi-level inverters is one of the finest structure requiring no clamping devices or elements. The structure of Cascaded H-Bridge topology is simple in onstruction but requires more number of DC sources to drive each individual H-Bridge cell.

A five-level cascaded H-Bridge structure consists of two H-Bridge cells cascaded with each individual H-Bridge cell is driven by DC source. Five-level cascaded H-Bridge structure of multi-level inverters is shown in Figure 2. Five-level output voltage in phase of cascaded H-Bridge is also shown in Figure 2. The total DC link voltage splits across two H-Bridge cells and by sequential triggering of power switches gives out five-level output. Table 1 illustrates the switching sequence of 5-level Cascaded H-Bridge with respect to power switches in Figure 2.

Table 1. Switching sequence of 5-level Cascaded H-Bridge

\begin{tabular}{lllllllll}
\hline Voltage Level & T1 & T2 & T3 & T4 & T5 & T6 & T7 & T8 \\
\hline Vdc & 1 & 1 & 0 & 0 & 1 & 1 & 0 & 0 \\
Vdc/2 & 1 & 1 & 0 & 0 & 1 & 0 & 1 & 0 \\
0 & 1 & 0 & 1 & 0 & 1 & 0 & 1 & 0 \\
- Vdc/2 & 0 & 0 & 1 & 1 & 1 & 0 & 1 & 0 \\
- Vdc & 0 & 0 & 1 & 1 & 0 & 0 & 1 & 1 \\
\hline
\end{tabular}

A multilevel UPQC for voltage and current quality improvement in distribution system (Veera Nagi Reddy.V) 


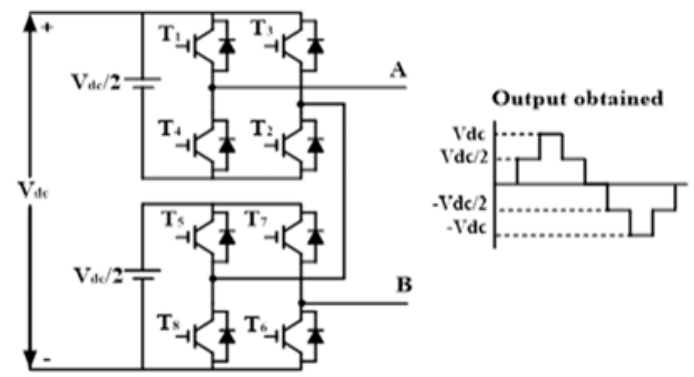

Figure 2. Cascaded H-Bridge structure of multi-level inverters

Figure 3 represents the 5-level UPQC connected in distribution system. In multi-level UPQC, both series and shunt controllers are 5-level CHB structured and only one-phase of CHB structured 5-level topology of series and shunt converters are represented for simplicity. Both the 5-level topology of series and shunt converters of UPQC is connected with a common DC-link capacitor. Both 5-level series and shunt controllers are controlled with a controller that gets feedback from source voltage and load current. Controller generates reference currents and triggering of power switches is done using pulse generator.

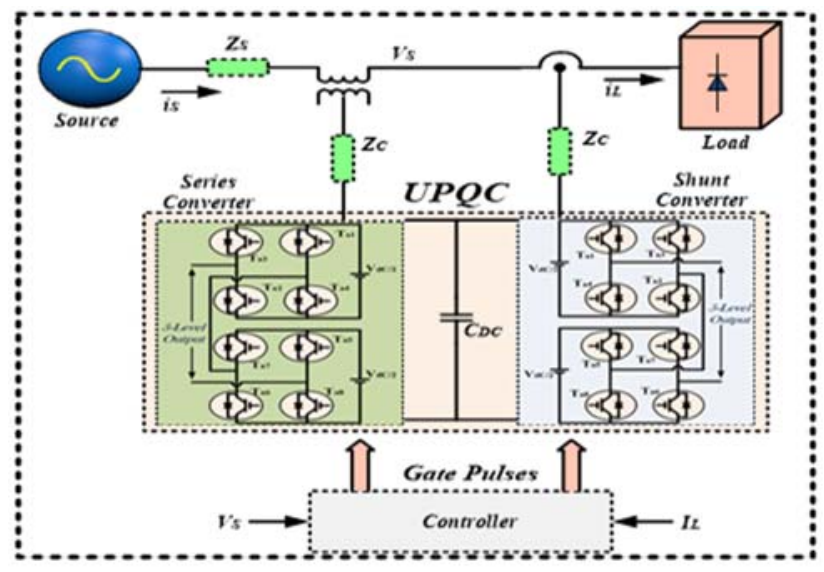

Figure 3. 5-Level UPQC in power system

\section{CONTROL ALGORITHM FOR UPQC}

3.1. Control algorithm for shunt controller

Shunt controller of UPQC mainly eliminates the harmonics in source currents. The reference currents to generate pulses to power switches of shunt controller in UPQC are produced from conventional 'PQ' theory. Actual DC-Link voltage is compared to reference value and the error is processed to PI controller to generate power loss component. Actual active power measured before is processed to summation block where power loss component (from PI controller) and actual active power are compared to generate one of the reference current signals in two co-ordinate system. Inverse transformation gives out the compensating reference signals. The compensating reference signlas are compared to line currents from power system to yield source reference currents. The obtained source reference currents are again compared to actual source currents to give out PWM reference signal. PWM reference signal when overlapped with level shifted carrier (LSCPWM pattern) signals produces pulses to power switches in shunt controller of UPQC. The complete schematic control algorithm for shunt controller of UPQC is shown in Figure 4. 


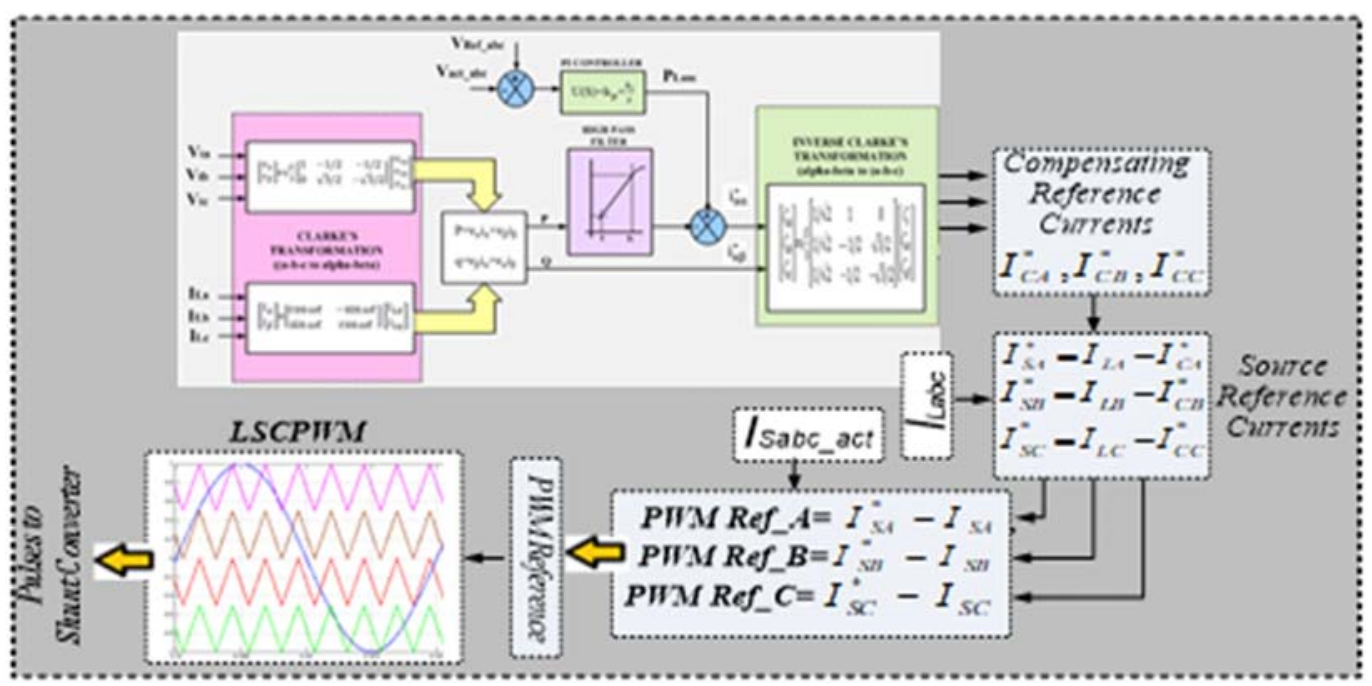

Figure 4. Control algorithm for shunt controller

\subsection{Control algorithm for series controller}

The series controller of UPQC mainly stabilizes or conditions the load voltage, which are the main criteria for sensitive loads. The control circuit to generate gate pulses to series converter of UPQC is shown in Figure 5. The three-phase source voltage is fed to three-phase phase locked loop (PLL) to get the information of phase angle. The phase angle obtained from PLL and the three-phase source voltage signal is processed to Clarke's transformation block where corresponding equations transform three-phase source voltage signals in to two co-ordinate signals in ' $\mathrm{d}-\mathrm{q}$ ' terms thus obtaining actual d-coordinate of voltage signal and actual q-coordinate of voltage signal. The actual values are compared to reference ' $d-q$ ' signals and the error is processed to PI controller which yields reference signals. These voltage reference signals in ' $\mathrm{d}$-q' coordinates along with phase angle information from PLL are processed to inverse transformation where again 'd-q' coordinates are transformed back to 'abc' signals. The three co-ordinates signals are fed to PWM generator to generate triggering pulses to switches of series converter of UPQC. The over-all diagram of 5-level UPQC with control algorithms is illustrated in Figure 6. Table 2 illustrates system parameters used for simulation analysis.

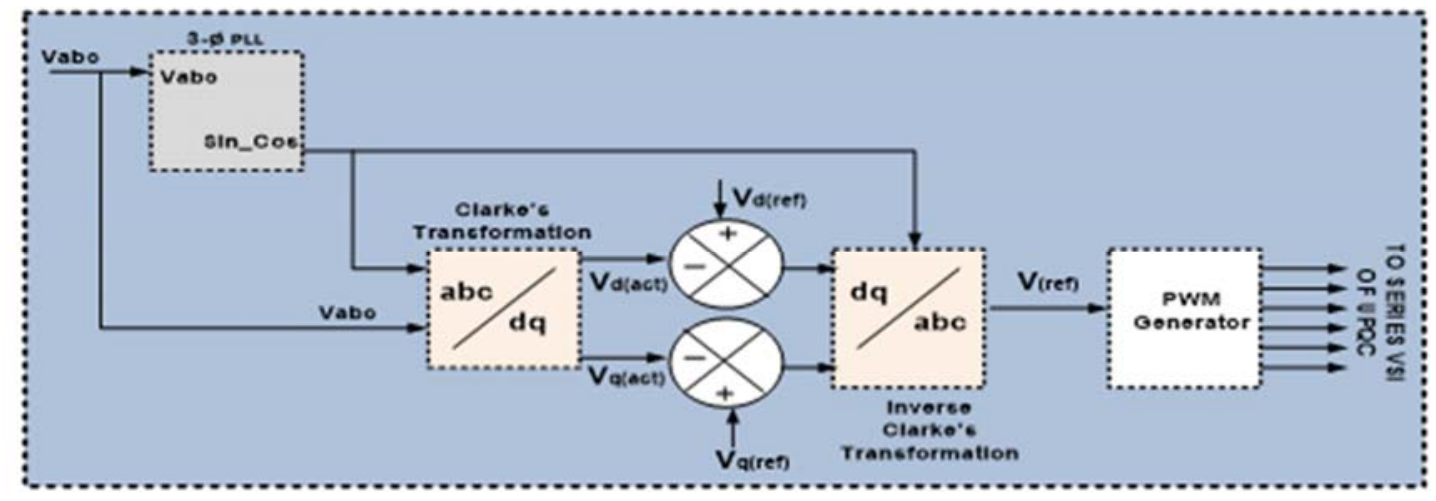

Figure 5. Control algorithm for series controller 


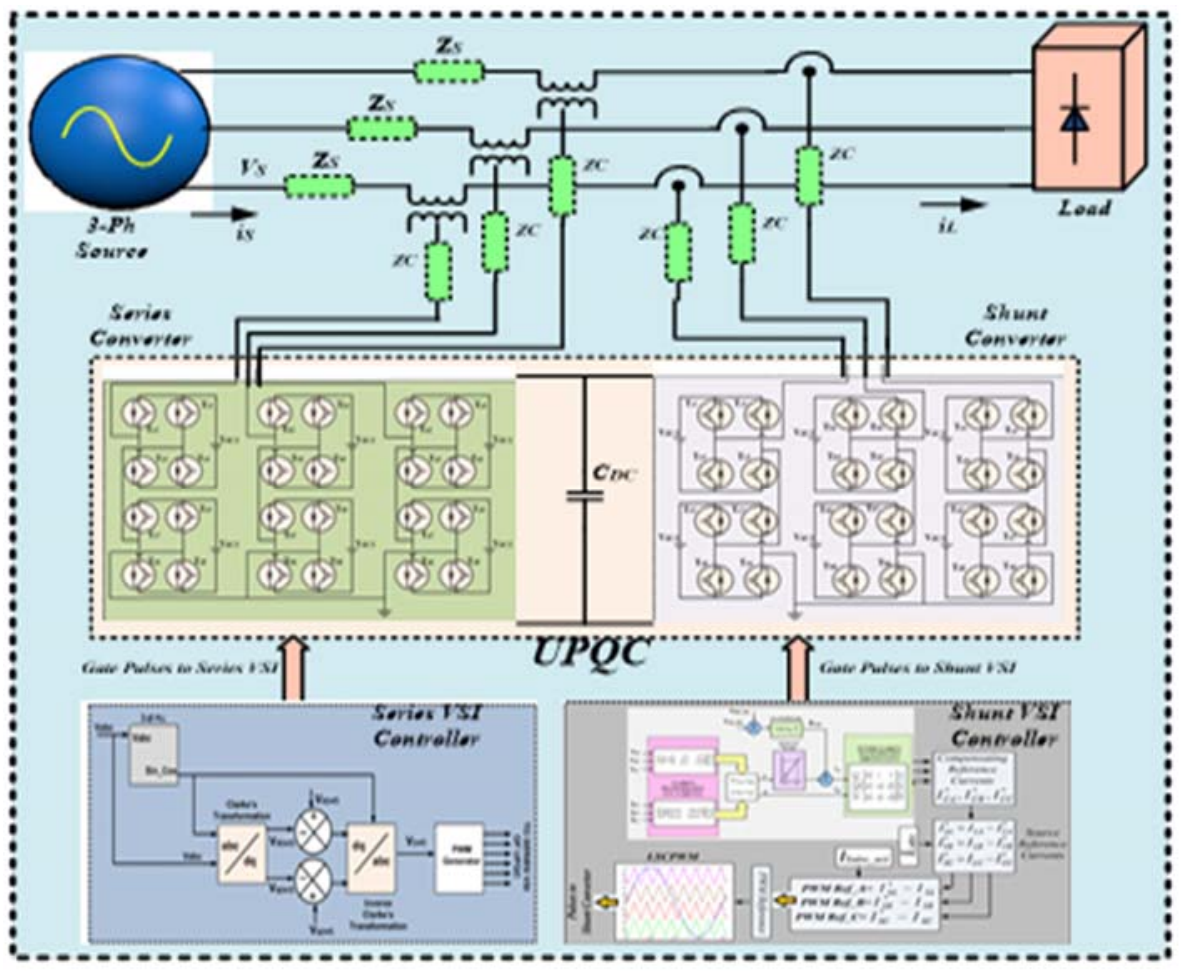

Figure 6. Overall schematic circuit of 5-level UPQC with control algorithms

Table 2. System parameters

\begin{tabular}{cc}
\hline Parameter & Value \\
\hline Source Voltage & $415 \mathrm{~V}, 50 \mathrm{~Hz}$ \\
Source impedance & $0.1 \mathrm{Ohms}, 0.9 \mathrm{mH}$ \\
Filter impedance & $0.001 \mathrm{Ohms}, 10 \mathrm{mH}$ \\
\hline
\end{tabular}

\section{RESULTS AND ANALYSIS}

\subsection{UPQC compensating sag and harmonics}

Figure 7 illustrates the power system parameters with UPQC showing source voltage, UPQC compensating voltage and Load voltage. Source voltage is programmed to contain sag in voltage during 0.3 seconds to 0.5 seconds. During this particular sag period, the load also should be affected with sag but UPQC (series converter) injects compensating signals to power system through series transformer and conditions the voltage to load. Compensating signals are injected during the sag period. The load voltage is not affected with sag and is maintained at constant peak.

Figure 8 shows the system parameters with UPQC connected in power system. Three-phase source voltage, source currents, load currents and compensating currents from UPQC are shown in Figure 8. As load is non-linear type, load current draws non-linear currents which affect source currents. Compensating signals from UPQC (shunt compensator) nullifies the affect of harmonics on source parameters. Source current is nearer sinusoidal with very less distortion and load current is non-linear in nature. Source voltage contains sag as explained in Figure 7.

Figure 9 illustrates the power factor on source side of power system. Source voltage and source current have almost the same phase and power factor tends to unity. Current signal is added with gain (to increase the amplitude) for better visualization.

Figure 10 shows the5-Level output before filtering from series controller of UPQC. CHB structure gives out 5-level output which is further filtered. Phase voltage with $300 \mathrm{~V}$ peak. 


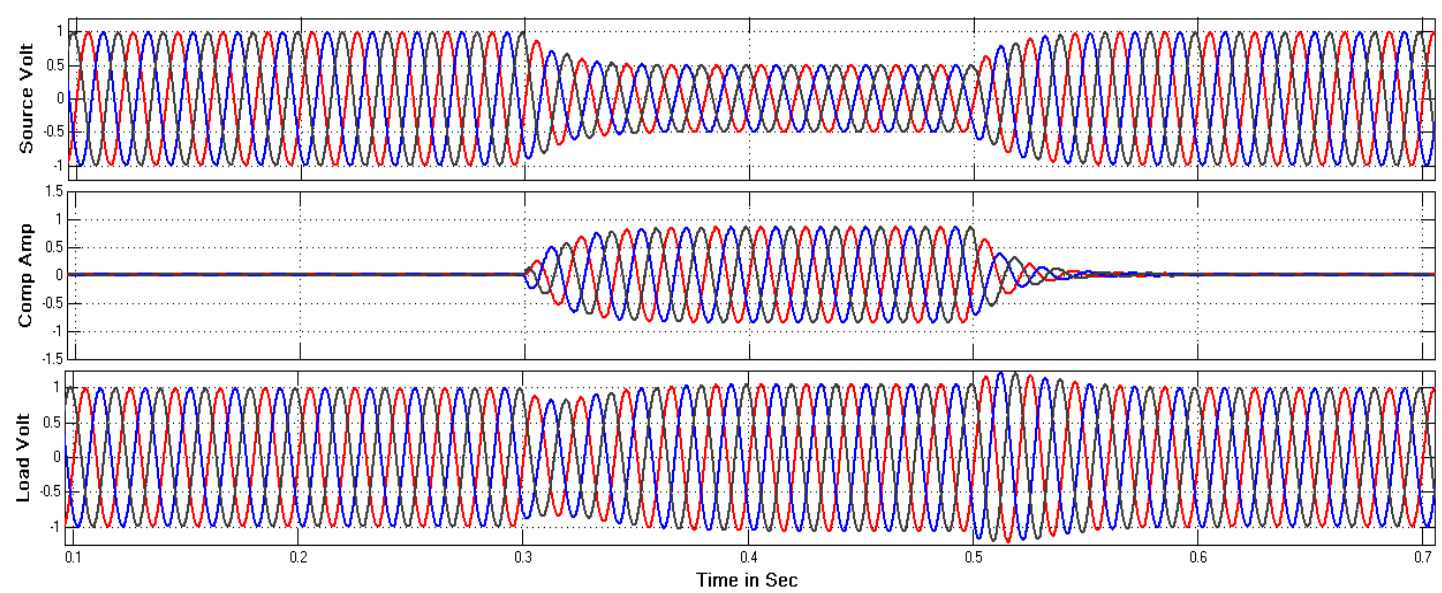

Figure 7. Source voltage, UPQC compensating voltage, Load voltage

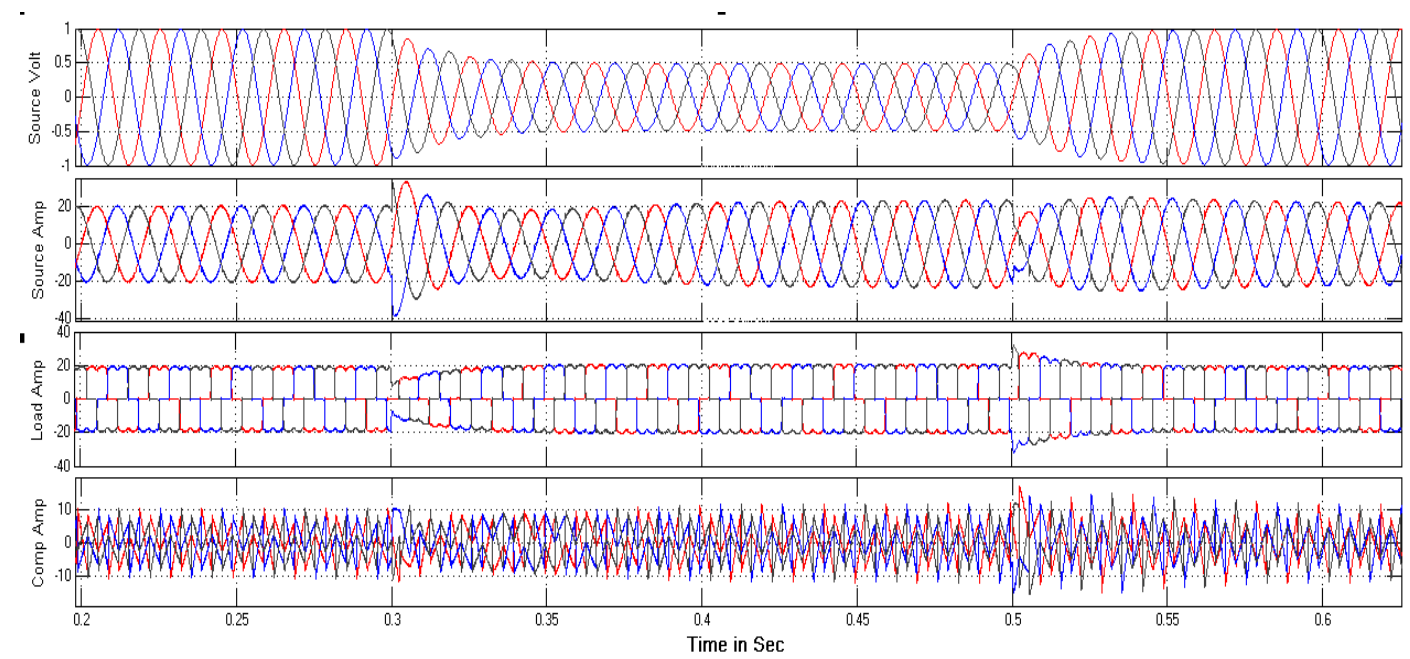

Figure 8. Source voltage, source currents, load currents and compensating currents of UPQC

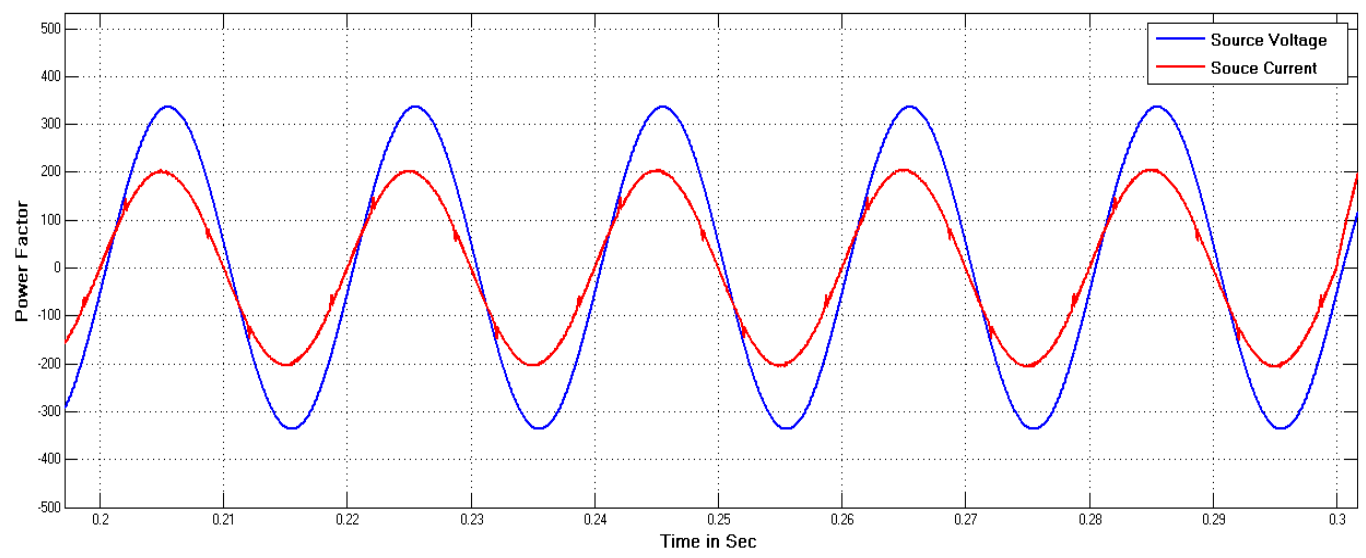

Figure 9. Source Power factor 


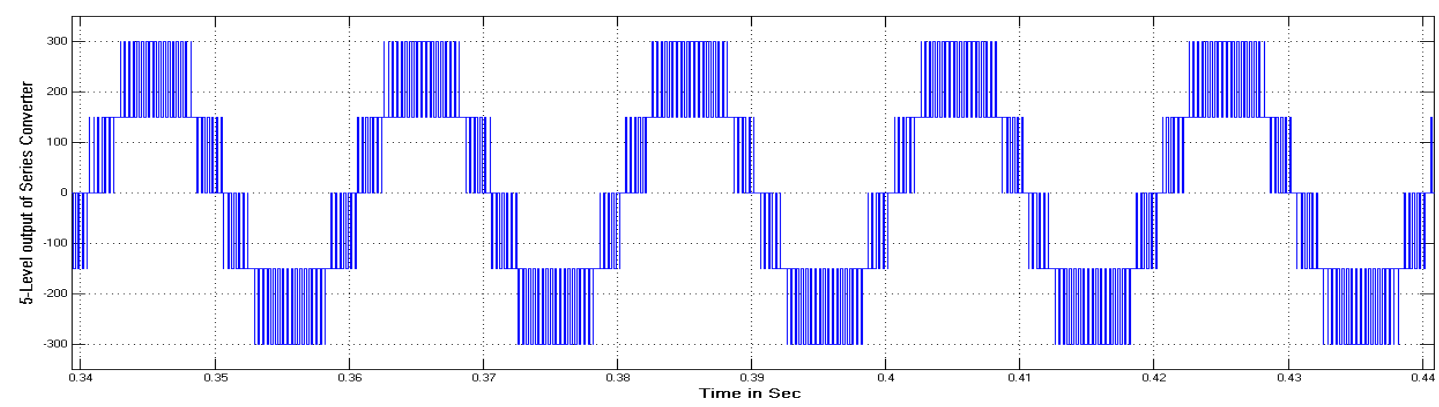

Figure 10. 5-Level output from series controller of UPQC

Figure 11 shows the5-Level output before filtering from shunt controller of UPQC. CHB structure gives out 5-level output which is further filtered. Phase voltage with $300 \mathrm{~V}$ peak.

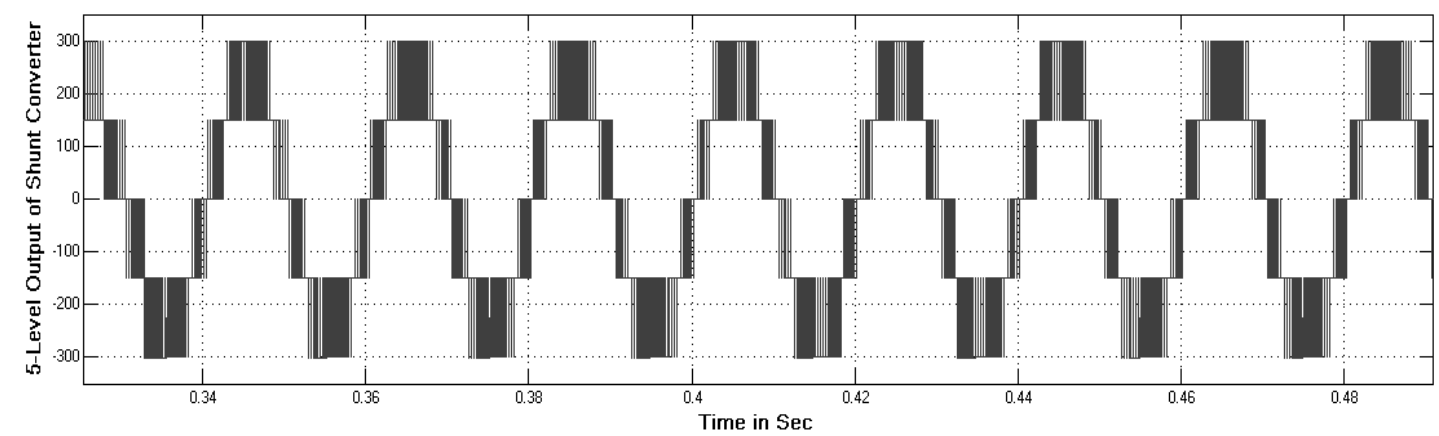

Figure 11. 5-Level output from shunt controller of UPQC

Figure 12 and Figure 13 shows harmonic analysis FFT windows of source and load current. Source current is distorted by $2.98 \%$ and load current by $29.46 \%$. Source current distortion is within nominal limit and load being non-linear in nature contains large distortion in current.
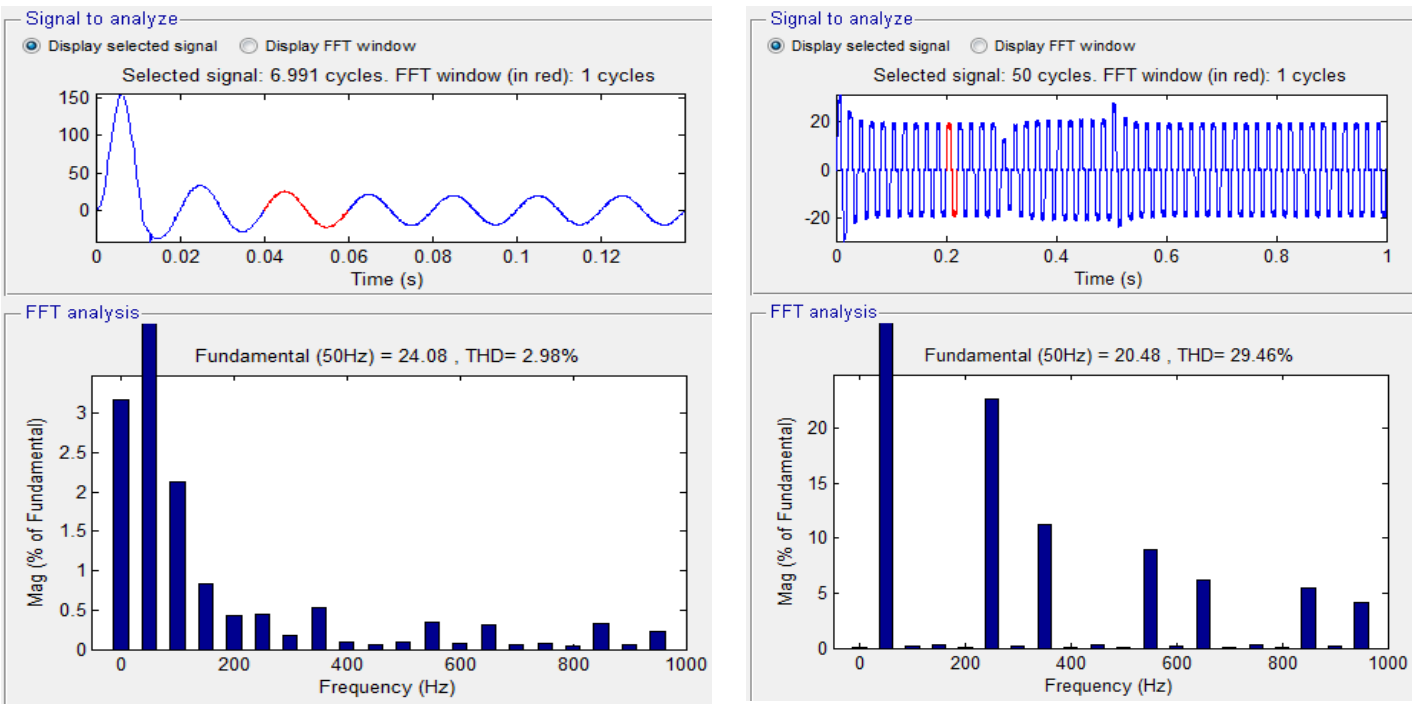

Int J Pow Elec \& Dri Syst Vol. 10, No. 4, Dec 2019 : 1932 - 1943 
Figure 12. THD in source current

Figure 13. THD in load current

\subsection{UPQC compensating swell and harmonics}

Figure 14 illustrates the power system parameters with UPQC showing source voltage, UPQC compensating voltage and Load voltage. Source voltage is programmed to contain swell in voltage during 0.3 seconds to 0.5 seconds. During this particular swell period, the load also should be affected with swell but UPQC (series converter) injects compensating signals to power system through series transformer and conditions the voltage to load. Compensating signals are injected during the sag period. The load voltage is not affected with sag and is maintained at constant peak.

Figure 15 shows the system parameters with UPQC connected in power system. Three-phase source voltage, source currents, load currents and compensating currents from UPQC are shown in Figure 15. As load is non-linear type, load current draws non-linear currents which affect source currents. Compensating signals from UPQC (shunt compensator) nullifies the affect of harmonics on source parameters. Source current is nearer sinusoidal with very less distortion and load current is non-linear in nature. Source voltage contains swell as explained in Figure 14.

Figure 16 illustrates the power factor on source side of power system. Source voltage and source current have almost the same phase and power factor tends to unity. Current signal is added with gain (to increase the amplitude) for better visualization.

Figure 17 shows the 5-Level output before filtering from series controller of UPQC. CHB structure gives out 5-level output which is further filtered. Phase voltage with $300 \mathrm{~V}$ peak.

Figure 18 shows the5-Level output before filtering from shunt controller of UPQC. CHB structure gives out 5-level output which is further filtered. Phase voltage with $300 \mathrm{~V}$ peak

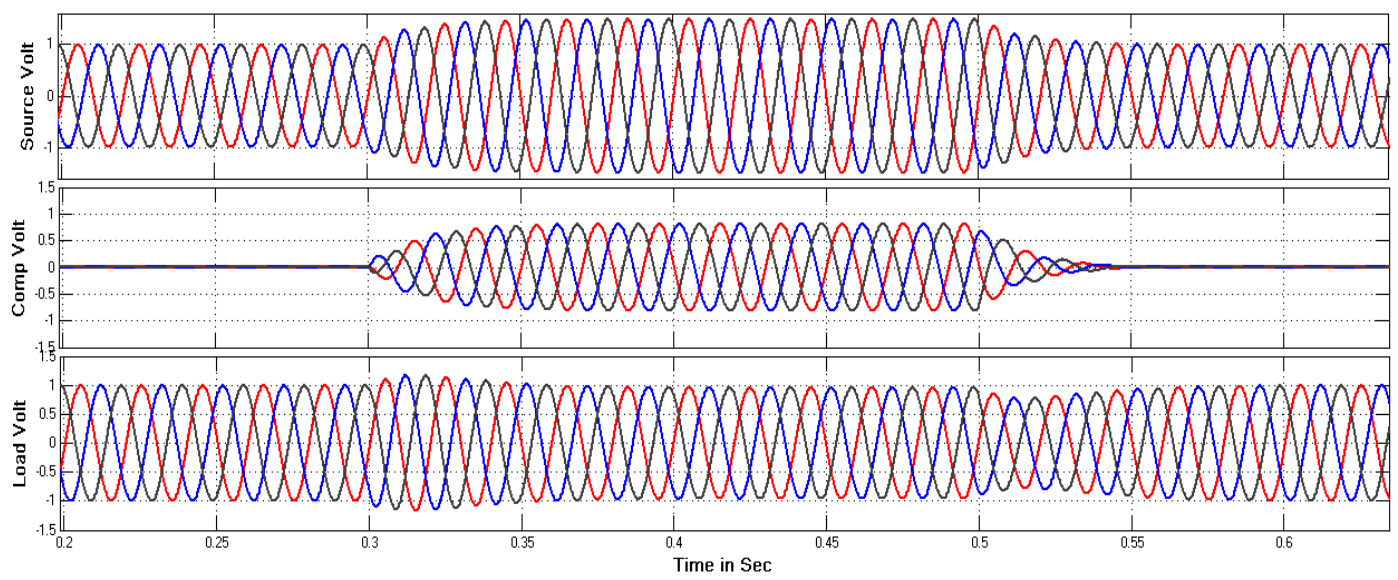

Figure 14. Source voltage, UPQC compensating voltage, Load voltage

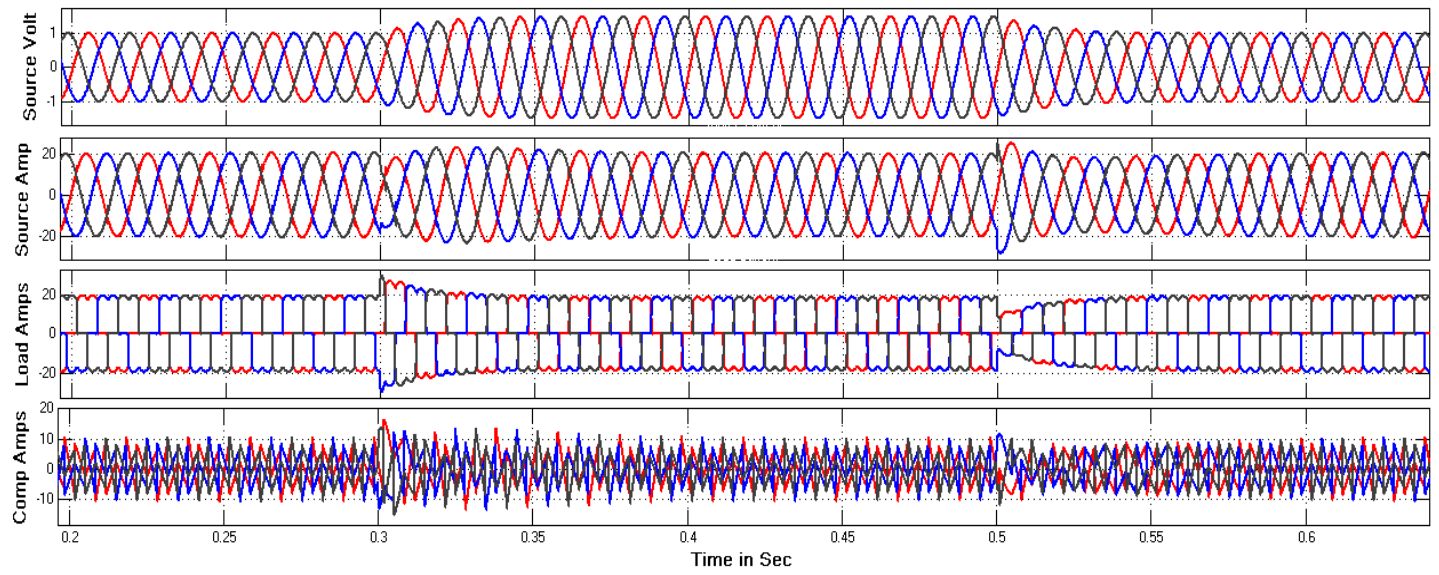

Figure 15. Source voltage, source currents, load currents and compensating currents of UPQC 


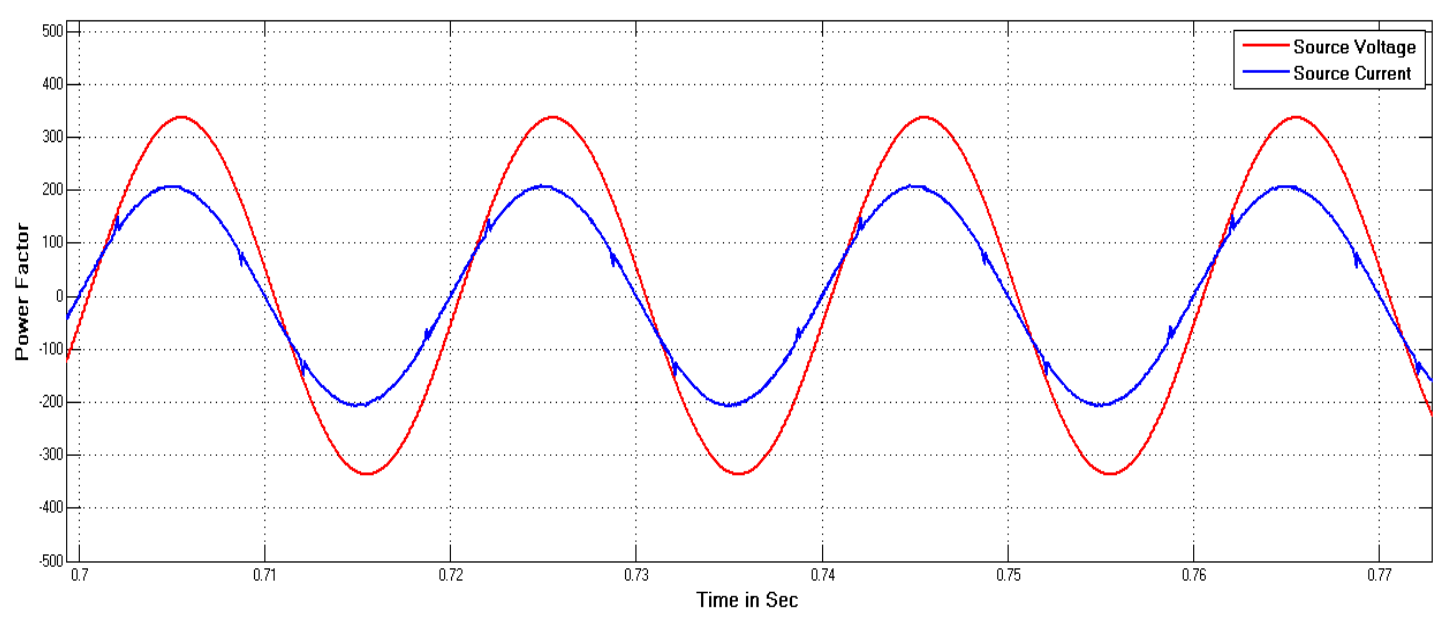

Figure 16. Source Power factor

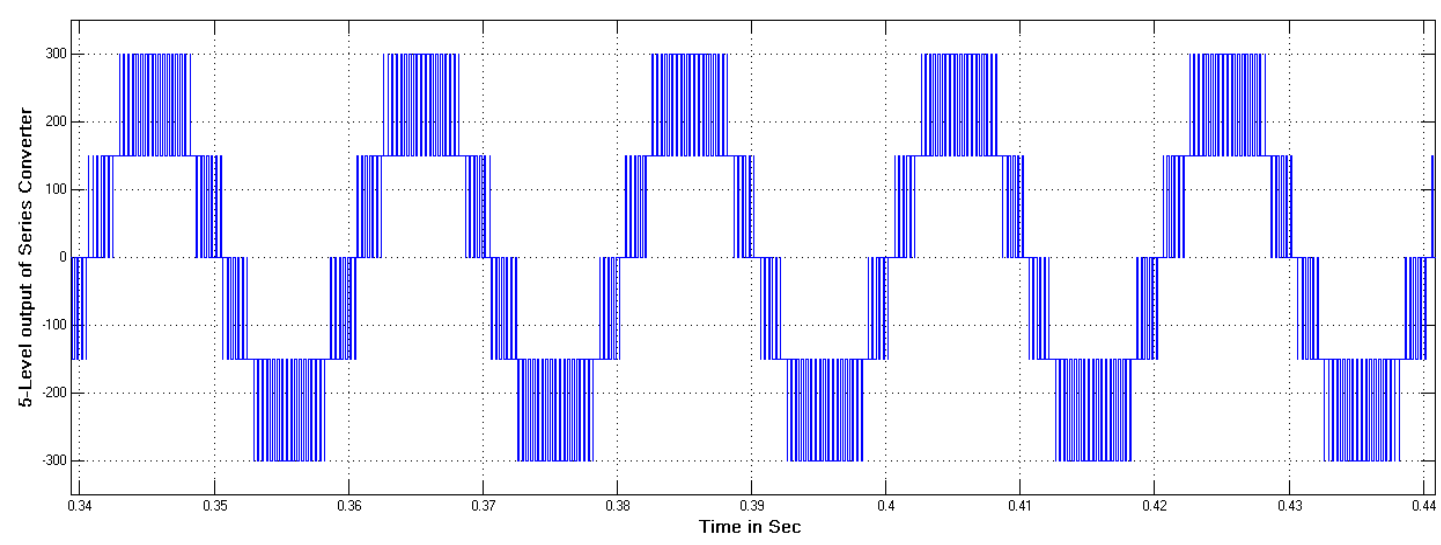

Figure 17. 5-Level output from series controller of UPQC

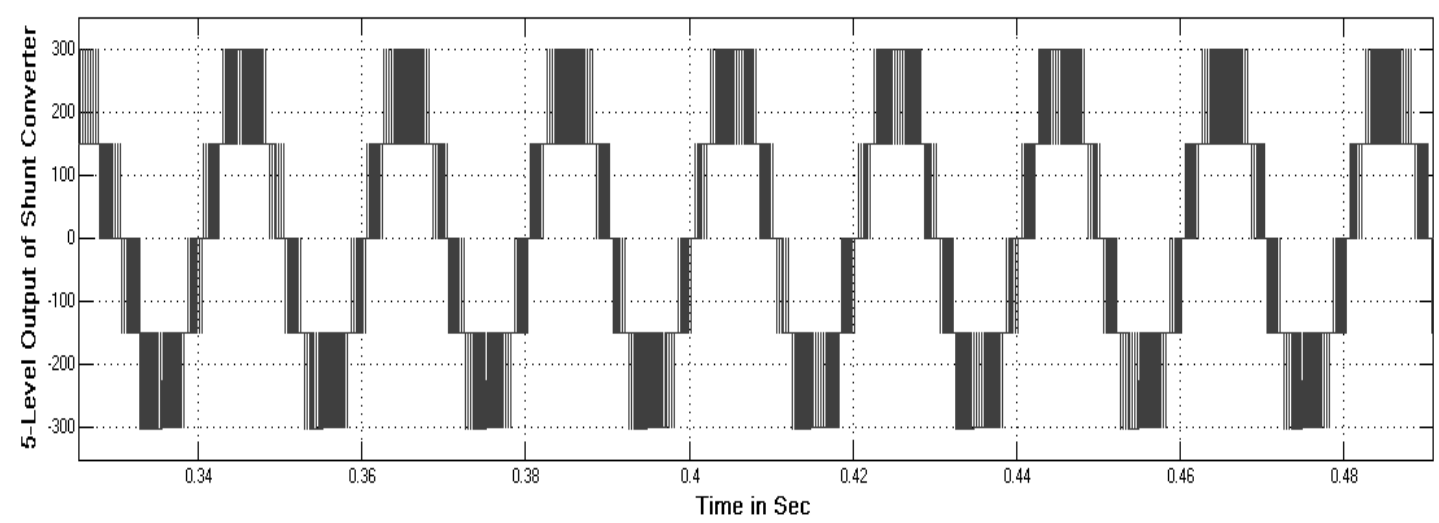

Figure 18. 5-Level output from shunt controller of UPQC 
Figure 19 and Figure 20 shows harmonic analysis FFT windows of source and load current. Source current is distorted by $2.09 \%$ and load current by $29.37 \%$. Source current distortion is within nominal limit and load being non-linear in nature contains large distortion in current.

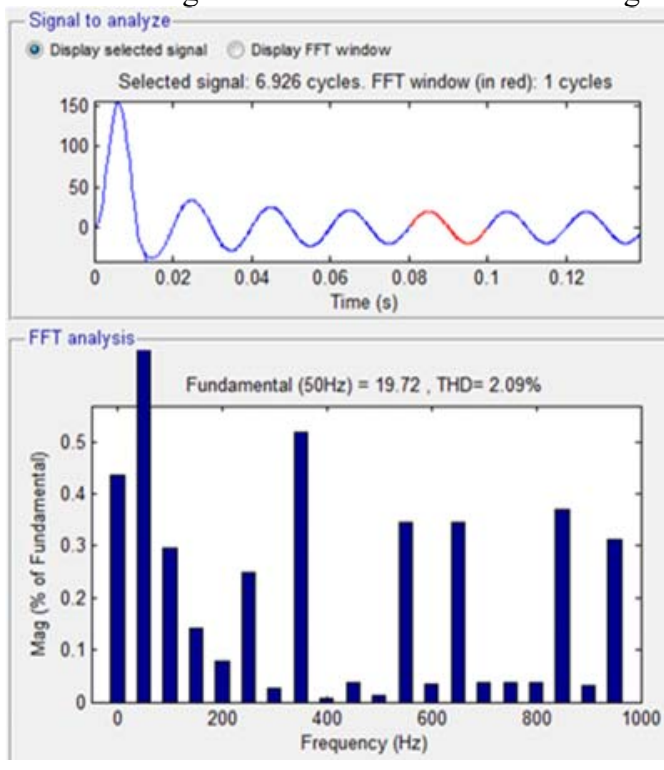

Figure 19. THD in source current
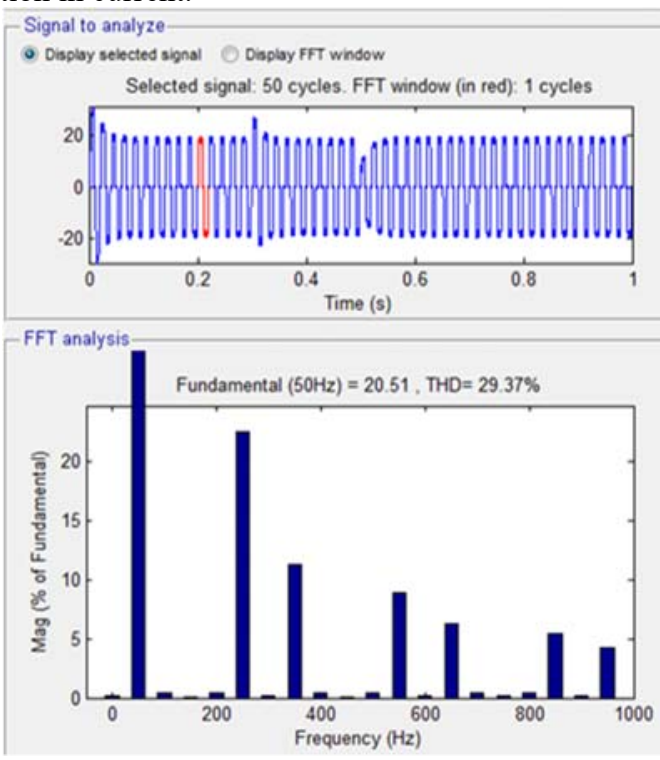

Figure 20. THD in load current

Table 3 shows the harmonic analysis with UPQC in different working conditions. In both the cases source current is within nominal limit.

Table 3. Harmonic analysis

\begin{tabular}{ccc}
\hline Condition & THD in Source Current & THD in Load Current \\
\hline Voltage Sag in power system & $2.98 \%$ & $29.46 \%$ \\
Voltage Swell in power system & $2.09 \%$ & $29.37 \%$ \\
\hline
\end{tabular}

\section{CONCLUSION}

Worsen of voltage or current in power distribution system is due to large usage of non-linear equipments and power electronic converters and due to load factors. UPQC is a FACTS based controller used in power system to enhance the power quality. The paper presents 5-Level CHB structured UPQC for the improvement of voltage and current in power distribution system. Series and shunt controllers of UPQC are5Level inverters, injecting compensating signals to condition the voltage and current respectively. Series controller is controlled using voltage reference SRF control and shunt controller is controlle with PQ based algorithm. Control algorithms with 5-level CHB UPQC are verified to compensate sag/swell in source voltage with simultaneous harmonic suppression in source current. Harmonics in source current is maintained within nominal values. Control algorithms are explained in detail.

\section{REFERENCES}

[1] R. Divya, S. M. Nandukrishnan and M. G. Nair, "Hardware implementation of power sharing and power quality improvement for grid integration of microgrid," 2017 International Conference on Technological Advancements in Power and Energy ( TAP Energy), Kollam, India, 2017, pp. 1-6.

[2] R. Kalpana, S. C. Khimavath, S. P. P and B. Singh, "Power Quality Enhancement Using Current Injection Technique in a Zigzag ConFigured Autotransformer Based 12-Pulse Rectifier," in IEEE Transactions on Industry Applications, 2018 (early access).

[3] V. Khadkikar "Enhancing electric power quality using UPQC: A comprehensive overview," IEEE Trans. Power Electron. vol. 27 no. 5 pp. 2284-2297 2012.

[4] A. Luo H. Xiao F. Ma et al. "Distribution static compensator based on an improved direct power control strategy," IET Power Electron. vol. 7 no. 4 pp. 957-964 2014.

[5] C. Kumar M.K. Mishra "An improved hybrid DSTATCOM topology to compensate reactive and nonlinear loads," IEEE Trans. Ind. Electron. vol. 61 no. 12 pp. 6517-6527 2014.

A multilevel UPQC for voltage and current quality improvement in distribution system (Veera Nagi Reddy.V) 
[6] T. S. Saggu, L. Singh and B. Gill, "Harmonics Mitigation in a Steel Industry Using 11-Level Cascaded Multilevel Inverter-Based DSTATCOM," in Canadian Journal of Electrical and Computer Engineering, vol. 40, no. 2, pp. 110-115, Spring 2017.

[7] K. M. Rafi and P. V. N. Prasad, "Comparision of control algorithms for power factor correction in a distribution system using DSTATCOM," 2017 IEEE International Conference on Power, Control, Signals and Instrumentation Engineering (ICPCSI), Chennai, India, 2017, pp. 1736-1741

[8] A. A. Patel and A. A. Patel, "Application of DSTATCOM for harmonics elimination and power quality improvement," 2017 International Conference on Energy, Communication, Data Analytics and Soft Computing (ICECDS), Chennai, India, 2017, pp. 3007-3011.

[9] G. Mallesham and C. S. Kumar, "Enhancement of power quality using UPQC for hybrid PEMFC and DFIG based wind energy system connected to weak grid," 2017 International Conference on Technological Advancements in Power and Energy ( TAP Energy), Kollam, India, 2017, pp. 1-6.

[10] M. Pradhan and M. K. Mishra, "Dual P-Q Theory based Energy Optimized Dynamic Voltage Restorer for Power Quality Improvement in Distribution System," in IEEE Transactions on Industrial Electronics, 2018 (early access).

[11] Tien, Dung, Radomir Gono, and Zbigniew Leonowicz. "A multifunctional dynamic voltage restorer for power quality improvement," Energies, vol. 11(6), pp. 1351, 2018.

[12] Amalorpavaraj, Rini Ann Jerin, et al. "Power quality improvement of grid connected wind farms through voltage restoration using dynamic voltage restorer," International Journal of Renewable Energy Research (IJRER), vol. 6(1), pp. 53-60, 2016.

[13] Ramasamy, M., and S. Thangavel. "Photovoltaic based dynamic voltage restorer with power saver capability using PI controller," International Journal of Electrical Power \& Energy Systems, vol 36(1), p. 51-59, 2012.

[14] Omar, R., and N. A. Rahim. "Voltage unbalanced compensation using dynamic voltage restorer based on supercapacitor," International Journal of Electrical Power \& Energy Systems, vol. 43(1), pp. 573-581, 2012.

[15] Chandrasekaran, K., and Vigna Kumaran Ramachandaramurthy. "An improved Dynamic Voltage Restorer for power quality improvement," International Journal of Electrical Power \& Energy Systems, vol. 82, pp. 354-362, 2016.

[16] Bagheri, Mehdi, et al. "Enhancing power quality in microgrids with a new online control strategy for DSTATCOM using reinforcement learning algorithm," IEEE Access, vol. 6, pp. 38986-38996, 2018.

[17] Gandoman, Foad H., et al. "Review of FACTS technologies and applications for power quality in smart grids with renewable energy systems," Renewable and sustainable energy reviews, vol. 82, pp. 502-514, 2018.

[18] Mahela, Om Prakash, and Abdul Gafoor Shaik. "Power quality improvement in distribution network using DSTATCOM with battery energy storage system," International Journal of Electrical Power \& Energy Systems, vol. 83, pp. 229-240, 2016.

[19] Iqbal, Fahad, Mohd Tauseef Khan, and Anwar Shahzad Siddiqui. "Optimal placement of DG and DSTATCOM for loss reduction and voltage profile improvement," Alexandria Engineering Journal, vol. 57(2), pp. 755-765, 2018.

[20] Kannan, V. Kamatchi, and N. Rengarajan. "Photovoltaic based distribution static compensator for power quality improvement," International Journal of Electrical Power \& Energy Systems, vol. 42(1), pp. 685-692, 2012.

[21] KHOMSI, Chiraz. "Power quality improvement in a three-phase grid tied photovoltaic system supplying unbalanced and nonlinear loads." International Journal of Renewable Energy Research (IJRER), vol. 8(2), pp. $1165-1177,2018$.

[22] Latran, Mohammed Barghi, Ahmet Teke, and Yeliz Yoldaş. "Mitigation of power quality problems using distribution static synchronous compensator: a comprehensive review," IET power electronics, vol. 8(7), pp. 1312-1328, 2015.

[23] S. Shen, H. Zheng, Y. Lin and W. Zhao, "UPQC Harmonic Detection Algorithm Based on Improved p-q Theory and Design of Low-Pass Filter," 2018 Chinese Control And Decision Conference (CCDC), Shenyang, China, 2018, pp. 5156-5160

[24] S. A. O. d. Silva, L. B. Garcia Campanhol and V. d. Souza, "Dynamic Performance Evaluation of a dual UPQC Operating Under Power Quality Disturbances," PCIM Europe 2018; International Exhibition and Conference for Power Electronics, Intelligent Motion, Renewable Energy and Energy Management, Nuremberg, Germany, 2018, pp. 1-8.

[25] V. Muneer, J. Sukumaran and A. Bhattacharya, "Investigation on reduced DC link voltage based UPQC for harmonic compensation under unbalanced load," 2017 International Conference on Technological Advancements in Power and Energy (TAP Energy), Kollam, India, 2017, pp. 1-6

[26] J. Ye, H. B. Gooi and F. Wu, "Optimal Design and Control Implementation of UPQC Based on Variable Phase Angle Control Method," in IEEE Transactions on Industrial Informatics, vol. 14, no. 7, pp. 3109-3123, Jul 2018

Int J Pow Elec \& Dri Syst Vol. 10, No. 4, Dec 2019 : 1932 - 1943 


\section{BIOGRAPHIES OF AUTHORS}
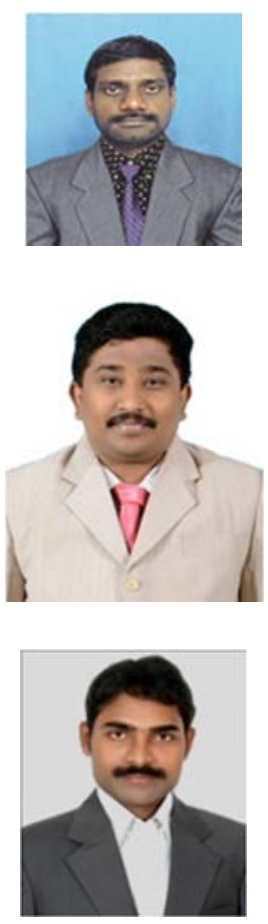

Mr. V.Veera Nagi Reddy, Research scholar, JNTUK, KAKINADA, A.P, India, is graduated in 2004. He obtained masters degree from JNTU, Anantapur, India. Currently, he is working as HOD \& Assistant Professor in electrical and electronics engineering department at MJRCET, A.P, INDIA. He is working towards his Ph.D. degree in JNTUK, KAKINADA. His research interests include soft computing techniques, smart grids, distributed generation systems and renewable energy sources.

Dr. D. V. Ashok Kumar is graduated in 1996, Masters in 2000 from J.N.T.U.C.E, Anantapuramu, and $\mathrm{Ph} . \mathrm{D}$ in 2008 from the same university. He worked 12 years at R.G.M. College of Engineering Technology, Nandyal, A. P. in the cadres of Assistant Professor, Assoc. Professor, Professor and Head of Electrical and Electronics Engineering Department. He worked as the Principal at Syamaladevi Institute of Technology for Women, Nandyal from 2008 to June 2015. He is working as Professor in E.E.E Dept., and Director of Administration \& Placements from July 2015 to till date. He has published 58 research papers in national and international conferences and journals. He has attended 15 National \& International workshops. His areas of interests are Electrical Machines, Power Systems \& Solar Energy. He is a senior member of IEEE, Fellow of IE, Life Member of I.S.T.E, K. D.T. F \& S.E.S.I.

Dr. Venkata Reddy Kota is currently working as Assistant Professor in the Department of Electrical and Electronics Engineering at Jawaharlal Nehru Technological University Kakinada, Andhra Pradesh. Dr. Reddy has received his Ph.D. (Electrical Engineering) JNTUK Kakinada, India in 2012. Dr. Reddy is a member of IEEE, the Institution of Engineers (India) and Indian Society for Technical Education. He is a recipient of the "IEI Young Engineers Award" from the Institution of Engineers (India) in 2013. He is a recipient of the "Tata Rao Prize" from the Institution of Engineers (India) in 2012. His areas of interest Include Special Electrical Machines, Electric Drives, FACTS and Custom Power Devises and Power Quality 